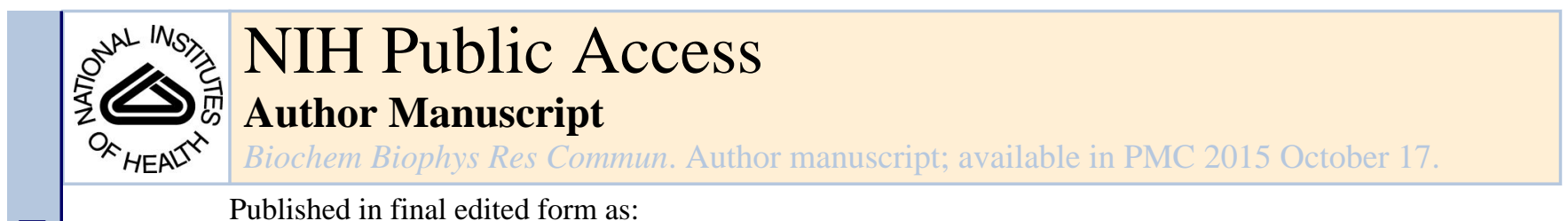

Published in final edited form as:

Biochem Biophys Res Commun. 2014 October 17; 453(2): 220-228. doi:10.1016/j.bbrc.2014.06.021.

\title{
MANNOSE METABOLISM: MORE THAN MEETS THE EYE
}

Vandana Sharma, Mie Ichikawa, and Hudson H. Freeze

Sanford-Burnham Medical Research Institute, La Jolla, CA 92037, USA

\begin{abstract}
Mannose is a simple sugar with a complex life. It's a welcome therapy for genetic and acquired human diseases, but it kills honeybees and blinds baby mice. It could cause diabetic complications. Mannose chemistry, metabolism, and metabolomics in cells, tissues and mammals can help explain these multiple systemic effects. Mannose has good, bad or ugly outcomes depending on its steady state levels and metabolic flux. This review describes the role of mannose at cellular level and its impact on organisms.
\end{abstract}

\section{Introduction}

Nearly all studies of mammalian sugar metabolism focus exclusively on glucose because of its central role in energy generation, storage and regulation. In medicine, glucose is also the focus because of diabetes and obesity. Other hexoses (mannose and galactose) receive relatively little attention in metabolic studies. These monoaccharides can be converted into glucose for catabolism or be derived from glucose for glycan biosynthesis.

Mannose occurs in multiple glycoconjugates. For nearly 40 years [1], [2-- $\left.{ }^{3} \mathrm{H}\right]-$ Mannose $\left(\left[2-{ }^{3} \mathrm{H}\right]-\mathrm{Man}\right)$ served as convenient biosynthetic label for mannose-containing glycans, helping to elucidate and quantify multiple biosynthetic pathways. The label is highly specific: catabolism of $\left[2-{ }^{3} \mathrm{H}\right]$-Man releases ${ }^{3} \mathrm{HOH}$, which is immediately diluted into an ocean of $\mathrm{H}_{2} \mathrm{O}$ so other hexoses are not labeled.

When mannose became an effective therapeutic for glycosylation-deficient patients [2], it called for a more in-depth understanding of mannose metabolism at both the cellular and organismic levels. Mannose can be a life saving therapeutic and a non-antibiotic treatment for selected bacterial infections [3], but in other situations it can be lethal [4] or teratogenic [5], underscoring the importance of stringent regulation of mannose metabolism. In this review, we will discuss mannose origins, metabolism, fate in cells, animals and humans, and its therapeutic applications.

(C) 2014 Elsevier Inc. All rights reserved.

Publisher's Disclaimer: This is a PDF file of an unedited manuscript that has been accepted for publication. As a service to our customers we are providing this early version of the manuscript. The manuscript will undergo copyediting, typesetting, and review of the resulting proof before it is published in its final citable form. Please note that during the production process errors may be discovered which could affect the content, and all legal disclaimers that apply to the journal pertain. 


\section{Mannose Chemistry}

D-Mannose is the 2-epimer of glucose and exists primarily as sweet-tasting $\alpha$ - $(67 \%)$ or as a bitter-tasting $\beta$ - (33\%) anomer of the pyranose [6,7]; furanose forms comprise $<2 \%$.

Mannose is $\sim 5 \mathrm{x}$ as active as glucose in non-enzyamtic glycation [8], which may explain why evolution did not favor it as a biological energy source. In the laboratory, mannose can be generated by oxidation of mannitol or by base-catalyzed epimerization of glucose through fructose [9]. L-Mannose is not normally used in biological systems; however, its structural similarity to naturally occurring L-rhamnose enables some plant enzymes to use L-mannose as an unnatural substrate in vitro [10]. Mutant strains of A. aerognees can use it as a sole carbon and energy source [11]

\section{Occurrence, origins and dietary sources of Mannose}

Mannose occurs in microbes, plants and animals. Free mannose is found in small amounts in many fruits such as oranges, apples and peaches [12] and in mammalian plasma at 50-100 $\mu \mathrm{M}$ [13]. More often, mannose occurs in homo-or hetero-polymers such as yeast mannans (a-mannose) where it can account for nearly $16 \%$ of dry weight [14] or in galactomannans [15]. Ivory nuts, composed of $\beta$-mannans (sometimes called vegetable ivory) are quite hard and used for carving and manufacturing buttons. In fact, ivory nut shavings were the original industrial source of mannose [16]. Coffee beans, fenugreek and guar gums are rich sources of galactomannans [17], but these plant polysaccharides are not degraded in the mammalian GI tract and, therefore, provide very little bio-available mannose for glycan synthesis. These polysaccharides are partially digested by anaerobic bacteria in the colon [18]. Small amounts of bio-available mannose occur in glycoproteins.

\section{Mannose Metabolism in cells}

Mannose is transported into mammalian cells via facilitated diffusion hexose transporters of the $S L C 2 A$ group (GLUT) present primarily on the plasma membrane. Various cell lines transport $6.5-23.0 \mathrm{nmols} / \mathrm{hr} / \mathrm{mg}$ protein [19], but no mannose-specific or -preferential transporters have been reported among the 14 distinct GLUT transporters found in humans [20]. Most studies of GLUT substrate specificity assess only transport of glucose and fructose, but very rarely mannose transport. Several reports describe SGLT-like mannose transporters in the intestine and kidney, where they could deliver free mannose from the diet or recover it from the urine [21]. To date, there is no evidence for the physiological importance of these transporters. Within the cell, mannose is phosphorylated by hexokinase (HK) to produce mannose-6-phosphate (Man-6-P), which serves as a common substrate for three competing enzymes. It is either catabolized by phosphomannose isomerase (MPI) or directed into $\mathrm{N}$-glycosylation via phosphomannomutase (PMM2). Another minor pathway utilizes mannose for synthesis of 2-keto-3-deoxy-D-glycero-D-galacto-nononic acid (KDN), a sialic-acid related molecule found in fish and mammals [22] (fig. 1). The fate of Man-6-P largely depends on the ratio of MPI to PMM2 within a cell [19] - higher ratio leads to greater catabolism, while lower ratio favors the glycosylation pathway. PMM2-derived mannose-1-phosphate (Man-1-P) is then incorporated into several glycosylation intermediates including GDP-mannose (GDP-Man), GDP-fucose, and dolichol phosphate 
mannose (Dol-P-Man). These intermediates then contribute to N-glycosylation, Oglycosylation, C-mannosylation, and GPI anchor synthesis (fig. 1).

GPI anchors play a significant role in protein sorting, trafficking and dynamics. All GPIanchors share a common core structure $\mathrm{H}_{2} \mathrm{~N}\left(\mathrm{CH}_{2}\right) 2 \mathrm{OPO}_{3} \mathrm{H}-6 \mathrm{Mana} 1->2 \mathrm{Mana1}$-> $6 \mathrm{Mana} 1$ $>$ 4GlcNa1->6Myo-Ino1-phospholipid [23]. The mannosyltransferases use Dol-P-Man. OMannose-based glycans are well known in yeast [24], but only identified 35 years ago in a mixture of unidentified brain proteoglycans [25]. Now, it is known that ER resident Protein O-mannosyl transferases 1 and 2 (POMT1 and POMT2) use Dol-P-Man to add mannose to serine and threonine residues, and the glycan is further extended by other monosaccharides in ER and Golgi [26]. Functional mutations in O-Mannose glycosylation are known to cause muscular dystrophies called a-dystroglycanopathies, since the major substrate protein is adystrogycan [27]. More recent studies show that a series of cadherins are also major carriers of O-mannose glycans [28]. C-mannosylation also uses Dol-P-Man to add mannose to C2 of tryptophan. The C-mannosyl transferase in the ER recognizes a concensus motif WXXW [29]. GPI anchors, O- and C- mannosylation have been reviewed extensively [29-33]. Since the majority of mannose is used for $\mathrm{N}$-glycosylation, we will focus on it.

Mannose is the major monosaccharide component of N-glycans and relies on ample supply of Man-6-P, Man-1-P, GDP-Man, and Dol-P-Man for synthesis of lipid linked oligosaccharides (LLO). The first five mannose residues are added on the cytoplasmic face of ER using GDP-Man. The glycan is then flipped to the luminal side via a flippase [34] and extended by four more mannose residues and glucose. This Man $\mathrm{Glc}_{3} \mathrm{GlcNAc}_{2}$ glycan is transferred to newly synthesized proteins soon after they emerge from the translocon or somewhat later [35]. A variable portion of LLO can also be hydrolyzed producing free oligosaccharides. Protein-bound N-glycans can undergo extensive mannose trimming, liberating free mannose within the ER and Golgi. Misfolded glycoproteins in the ER that fail to pass quality control are retro translocated into the cytoplasm and stripped of their glycans, which are further degraded in the cytoplasm and lysosome yielding free mannose [36-38] (fig. 2).

\section{Metabolic Fate of Mannose}

Since 1979 , the vast majority of biosynthetic studies have used $\left[2-{ }^{3} \mathrm{H}\right]-\mathrm{Man}$ as tracer to determine mannose incorporation into multiple glycosylation pathways. Following phosphorylation to $\left[2-{ }^{3} \mathrm{H}\right]-\mathrm{Man}-6-\mathrm{P}$, any further catabolism involves isomerization at the $\mathrm{C} 2$ position and release of ${ }^{3} \mathrm{HOH}$, which is immediately diluted into an ocean of $\mathrm{H}_{2} \mathrm{O} .{ }^{3} \mathrm{HOH}$ release provides an approximate measure of $\left[2-{ }^{3} \mathrm{H}\right]-\mathrm{Man}$ catabolism and has been used as a sensitive in vitro and live cell measure of MPI activity [2,39]. However, this label cannot address the mannose fate beyond Man-6-P. More recent studies show that mannose catabolism is nearly identical to glucose [40].

In mammalian cells, 95-98\% of mannose entering the cell via transporters is catabolized via MPI and only 2\% is used for N-glycosylation [13,19]. Labeling hepatoma cells with $\left[2-{ }^{3} \mathrm{H}\right]-$ Man shows incorporation into Man-6-P and Man-1-P within a few seconds and into GDP-Man within 5 min. ${ }^{3} \mathrm{H}$-labeled LLOs and free oligosaccharides reach a steady state in $15 \mathrm{~min}$ and $30 \mathrm{~min}$ respectively [19]. Chasing [2- $\left.{ }^{3} \mathrm{H}\right]-$ Man-labeled cells under physiological 
conditions of $5 \mathrm{mM}$ glucose and $50 \mu \mathrm{M}$ mannose showed that LLO turns over with a $\mathrm{t}_{1 / 2}=15$ min and more than $50 \%{ }^{3} \mathrm{H}$ - from cellular glycoproteins is released in first $1-2$ hours (glycan processing) followed by much slower rate of decrease (glycoprotein secretion or turnover) over the next 4 hours.

Surprisingly, mannose released by $\mathrm{N}$-glycan processing is handled differently than mannose entering the cell. $\mathrm{N}$-glycan processing mannose is shielded from hexokinase and transported outside the cell as free mannose, using an unidentified, nocodazole-sensitive transporter [19]. The reason for these separate tracks for intracellular mannose is unknown, but cells may need to purge mannose to avoid glycation or accumulation of other toxic products. Calculations estimate that the quantity of mannose exported from cells is sufficient to account for the steady state level of mannose in plasma [19].

Comparison of $\left[{ }^{14} \mathrm{C}\right]$-glucose and $\left[2-{ }^{3} \mathrm{H}\right]-$ Man incorporation at their physiological concentrations ( $5 \mathrm{mM}$ and $50 \mu \mathrm{M}$, respectively), suggested that cells derive most mannose from glucose [19]. We recently used ${ }^{13} \mathrm{C}$ or ${ }^{2} \mathrm{H}$ stable isotopes to label mannose in $\mathrm{N}$ glycans and determine whether it originated from glucose $\left(\mathrm{Man}^{\mathrm{G}}\right)$ or from mannose $\left(\mathrm{Man}^{\mathrm{M}}\right)$. Incorporated sugars in $\mathrm{N}$-glycans are released, hydrolyzed and the different fragments detected by GC-MS [40]. The general picture agrees with the results of radiolabeling, but the stable isotopes provide a much more precise quantitation.

In some cell lines, exogenous mannose can normally contribute up to $50 \%$ of the mannose to $\mathrm{N}$-glycans when provided at their physiological concentrations. Mannose is far more efficiently utilized than glucose: $1.8 \%$ of transported mannose appears in $\mathrm{N}$-glycans, but only $0.026 \%$ of transported glucose. At physiological concentration of $50 \mu \mathrm{M}$, mannose is undetectable in galactose (Gal) or N-acetyl glucosamine (GlcNAc) of N-glycans or glycogen. At $1 \mathrm{mM}$, mannose becomes the sole source of mannose in $\mathrm{N}$-glycans $\left(\mathrm{Man}^{\mathrm{M}}\right.$ ), and is easily detected in Gal and GlcNAc in N-glycans [40]. At this high concentration, most is catabolized to pyruvate, lactate and alanine, but not found in glycogen. This result suggests that glucose and mannose do not have equal access to the glycogen biosynthesis apparatus [40] implying despite their similarities, they may exist in distinct pools.

\section{Other sources of Mannose in N-glycans}

Glucose-derived Man in N-glycans $\left(\mathrm{Man}^{\mathrm{G}}\right.$ ) uses an MPI-dependent reaction that requires exchange of an $\mathrm{H}$ at $\mathrm{C} 2$ [40] (fig. 3). In the presence of $\mathrm{D}_{2} \mathrm{O}, \mathrm{D}$ is introduced at $\mathrm{C} 2$ [40]. Using this method, we found that mannose cannot be derived from glycogen $\left(\mathrm{Man}^{\mathrm{GL}}\right)$ under physiological conditions, during ER stress, or when glucose was limited, requiring complete degradation of glycogen stores. A similar approach using $\mathrm{D}_{2} \mathrm{O}$ showed that the contribution of mannose from gluconeogenesis or that salvaged $\left(\mathrm{Man}^{\mathrm{S}}\right)$ from $\mathrm{N}$-glycan degradation was insignificant [40].

The $\mathrm{D}_{2} \mathrm{O}$ labeling method also showed that about one-third of $\mathrm{Man}^{\mathrm{M}}$ found in $\mathrm{N}$-glycans is first converted to Fru-6-P and reconverted to Man-6-P again (fig. 3). This result shows that previous determinations of $\mathrm{Man}^{\mathrm{M}}$ had been underestimated by 1.5 -fold. Importantly, the transient fructose-6-phosphate (Fru-6-P) derived from Man-6-P does not equilibrate with the total cellular pool of Fru-6-P, suggesting the presence of at least two separate pools of 
Fru-6-P [40]. The existence of a distinct glycosylation-destined pool of Fru-6-P might help explain its highly efficient incorporation into glycoproteins. Surprisingly, more than $80 \%$ of glucose found in glycogen also transits through a Fru-6-P intermediate (Glc-6-P- $\rightarrow$ Fru-6$\mathrm{P} \rightarrow$ Glc-6-P) prior to its conversion to Glc-1-P and then to UDP-Glucose. It is unclear why both mannose and glucose incorporated into macromolecules take a seemingly unnecessary detour through Fru-6-P. It may mean that Fru-6-P has unrecognized function in controlling metabolic flux into these biosynthetic pathways.

Fluorescence Assisted Carbohydrate Electrophoresis (FACE) can measure steady state levels of intermediary mannose metabolites, including sugar phosphates, LLO and free glycans [41]. This important method demonstrated that when lightly permeabilized fibroblasts are incubated with $50 \mu \mathrm{M}$ Man-6-P, comparable to its normal intracellular level, it specifically cleaves only mature LLO, releasing $\mathrm{Glc}_{3} \mathrm{Man}_{9} \mathrm{GlcNAc}_{2}$ [41,42]. This effect was highly specific for Man-6-P and has been confirmed in another study, however, it failed to show any decrease in $\mathrm{N}$-glycosylation [43].

\section{Mannose metabolism in humans}

Human plasma contains $\sim 50 \mu \mathrm{M}$ mannose which is primarily derived from $\mathrm{N}$-glycan processing [19]. Mannose is absorbed through the intestine and metabolized. A bolus of $<0.2 \mathrm{~g} / \mathrm{Kg}$ body weight increases mannose concentration by 3 -fold with a clearance $\mathrm{T}_{1 / 2}$ of $4 \mathrm{hr}$, without affecting glucose concentration. Higher doses cause mild gastro-intestinal discomfort, but no other side effects [44]. Pregnant women with diabetes mellitus show elevated mannose levels in fasted blood and amniotic fluid which correlated with high glucose concentration [45] and several show that mannose levels are closely linked to glucose metabolism [46,47]. How this impacts glycosylation is not known.

Excreted mannose can have beneficial effects because it can treat urinary tract infections (UTI), the second most common reason for physician visits in the United States $[3,48]$. Most UTI infections are caused by E. coli, which bind to the epithelial cells via a mannosebinding lectin, FimH, located at the tip of the bacterial pillus [49]. Excreted mannose competes their binding. The only published clinical study shows that mannose is a prophylactic against reinfections [3]. The easy availability of mannose at health food stores and via internet suppliers make it a widely sold unregulated dietary supplement. Several websites describe it as safe, even for pregnant women, while others advise caution during pregnancy and breast-feeding. Currently, there are no reports of adverse effects of mannose in humans. More complex versions of competing glycans are also being studied [50].

Multiple genetic disorders disrupt intermediary mannose metabolism. Genetic defects in MPI and PMM2 cause MPI-CDG and PMM2-CDG, two congenital disorders of glycosylation (CDG). These patients have substantially reduced enzyme activities and suffer from multi-organ insufficiencies. PMM2-CDG is the most prevalent type of CDG, typically showing hypotonia, psychomotor retardation, cerebellar hypoplasia and cerebral atrophy [51-53]. MPI-CDG patients have hypoglycemia, coagulopathy, hepato-intestinal symptoms, and in some cases liver fibrosis [54], but they are neurologically normal [55]. 
MPI-CDG is unique among the glycosylation disorders since patients can be treated with dietary mannose supplements. As described above, the majority of mannose for glycosylation comes from glucose through Fru-6-P via MPI. Mannose supplements (0.5$0.75 \mathrm{~g} / \mathrm{kg}$ body weight/day) are sufficient to overcome MPI deficiency and restore normal glycosylation in patients [56]. Given the greater non-enzymatic glycation potential of mannose, it is important to monitor these patients for diabetic like complications [57]. Patients respond quickly to mannose and most symptoms abate. One exception is that liver abnormalities, like ductal plate malformation, which are evident at birth, are irreversible, and some patients progress to liver fibrosis [58] and liver failure requiring transplant. One MPI-CDG patient whose brother died from complications related to coagulopathy, appeared to lead a normal life without mannose treatment $[59,60]$. She consumed a normal diet and had three normal pregnancies. Her transferrin pattern showed signs of hypoglycosyaltion, which improved on mannose therapy, and reverted when mannose was stopped [59]. Two more asymptomatic patients with abnormal transferrin and 10-30\% residual MPI enzymatic activity were recently reported [61]. One hospitalized MPI-CDG patient was unable to take oral mannose and instead received it via infusion. This led to a rapid development of stupor and seizures, but a glucose bolus immediately reversed the symptoms. It is likely that mannose decreased glycolysis and ATP production in the brain, but glucose infusion competed out mannose transport [62].

PMM2-CDG patients have lower blood mannose levels $(5-40 \mu \mathrm{M})$ compared to normal individuals $(40-80 \mu \mathrm{M})$ [63]. This could be attributed to under-glycosylation of proteins that would generate less mannose from $\mathrm{N}$-glycan processing. Unfortunately, these patients do not benefit from mannose supplements and failed to show improvement in serum transferrin glycosylation as a surrogate marker [64,65]. Occasionally, families of these patients provide them with mannose hoping to see improvement, however, to date no published data show any clinical benefit. In patient cells, the Man-1-P deficiency can be overcome by providing membrane-permeable versions containing blocked phosphate and acetylated hydroxyl groups, but these compounds are unstable not useful therapeutically [66].

Besides mutations in $M P I$ and $P M M 2$, defects in other mannose-metabolizing enzymes cause human CDG's. Mutations in GMPPA and GMPPB, DPM1, DPM2, DPM3, and $M P D U 1$ directly effect the production of the various substrates and leads to pathology [51,67-74]. While these could theoretically impact all mannose-requiring pathways, patient phenotypes and demonstrated glycosylation abnormalities do not support a global and equal impact. Deficiencies in all but GMPPA, produce insufficient or incomplete LLO resulting in incomplete $\mathrm{N}$-glycosylation site occupancy. The phenotypic spectrum of the disorders is very broad and can affect many different organ systems (Table. 1). DPM1 deficiency reduces Dol-P-Man synthesis and also impacts the GPI anchor pathway [75]. Mutations in DPM3 decrease Dol-P-Man synthesis and reduce N-glycosylation, but they also cause a dystroglycanopathy [71]. GMPPB, the catalytic subunit for production of GDP-Mannose, does not appear to affect $\mathrm{N}$-glycosylation based on analysis of serum transferrin [68]. However, it affects the O-mannose pathway causing a dystroglycanopathy, presumably due to insufficient GDP-Man. Mutations in GMPPA, encoding a non-catalytic subunit, cause intellectual disability and neurological abnormalities, but surprisingly GDP-mannose levels 
are greatly increased in patient lymphoblasts, leading to the suggestion that GMPPA regulates GDP-Man levels [67].

Collectively, these studies underscore the variable phenotypic impact of disrupting mannose metabolism supplying different pathways and in different cells and tissues. It suggests that glycosylation load and metabolic flux must play critical roles in determining the outcome. Epigenetic phenomena may also make important contributions, but these have not been explored in these disorders [76].

\section{Mannose metabolism in animals}

Rat plasma contains $\sim 80 \mu \mathrm{M}$ mannose. Kinetics of gavaged $\left[2-{ }^{3} \mathrm{H}\right]$-Man uptake and clearance are similar to humans. Most of the label is catabolized and a few percent is incorporated into glycoproteins in all tissues including placenta and embryos. A gavage dose of $0.1 \mathrm{~g} / \mathrm{Kg}$ body weight increased serum mannose levels by 3.6 fold within 90 minutes without diarrhea [13]. Mice showed similar clearance kinetics of injected [2- $\left.{ }^{3} \mathrm{H}\right]-\mathrm{Man}$ [77]. Long-term mannose supplementation using 1-20\% mannose in the drinking water for 5 months had no obvious side effects. At $20 \%$ mannose, the total water consumption was decreased. Blood mannose increased up to $900 \mu \mathrm{M}$ with $20 \%$ mannose and milk increased from $60 \mu \mathrm{M}$ to $>500 \mu \mathrm{M}$ [77]. Mannose-fed pregnant mice had normal litter size and survival to weaning and all mice given mannose supplements had normal weight gain, organ function, physiology and behavior. These studies in mice indicated that mannose would be useful for MPI-CDG patients.

\section{Animal models of PMM2-CDG and MPI-CDG}

Mice deficient in Pmm2 and Mpi were created to model the human disorders. In both cases, complete knockout is lethal with Pmm2 null animals dying shortly after fertilization [78] and Mpi-null about mid-gestation [39]. This led to the creation of hypomorphic mouse lines for both genes and to morpholino-based models in zebrafish $[79,80]$.

\section{Pmm2 animal models}

Zebrafish: Low cost, facile genetic manipulation, and easy monitoring of early development make this animal an attractive model system. Morpholino-mediated knockdown of pmm 2 showed craniofacial defects and altered motor neurogenesis similar to PMM2-CDG patients [79]. FACE analysis of homogenized embryos showed decreased LLO, increased free oligosaccharides, and reduced overall $\mathrm{N}$-glycosylation. This is accompanied by 1.6-fold increase in Man-6-P, which is presumably responsible for LLO hydrolysis and under-glycosylation of proteins. This is the first evidence that blocking $\mathrm{Pmm} 2$ activity can raise the average level of Man-6-P in a whole organism.

Mice: Pmm2 null embryos die around embryonic stage, E3.5, presumably due to hypoglycosylation of proteins including those of the zona pellucida [78]. Since PMM2-CDG patients have residual enzymatic activity, C57BL/6 hypomorphic mouse lines were generated by knocking-in mutations that are nearly equivalent to corresponding PMM2CDG patient mutations, R141H and F119L [81]. Pmm2 $2^{\mathrm{R} 137 \mathrm{H} / \mathrm{R} 137 \mathrm{H}}$ mice did not survive beyond E5.5 because the residual activity is essentially zero. Pmm $2^{\text {F118L/F118L }}$ pups were 
viable and comparable to wild type normal mice. Recombinant PMM2 proteins showed almost no activity in R137H and 42\% residual enzymatic activity in homozygous F118L mutants. Intercrossing of $P m m 2^{\mathrm{R} 137 \mathrm{H} /+}$ and $P m m 2^{\mathrm{F} 118 \mathrm{~L} /+}$ produced $P m m 2^{\mathrm{R} 137 \mathrm{H} / \mathrm{F} 118 \mathrm{~L}}$ embryos with $11 \%$ residual PMM2 activity. These embryos survived up to E10.5. However, providing $9 \mathrm{mg} / \mathrm{ml}(0.9 \% \mathrm{w} / \mathrm{v})$ mannose in the drinking water before conception and continuing through gestation rescued the embryos and live pups were born [81]. Mannose supplements increased mannose concentration in mother's blood by 1.8 fold, which was thought to drive more mannose into the glycosylation pathway of $P m m 2^{\mathrm{R} 137 \mathrm{H} / \mathrm{F} 118 \mathrm{~L}}$ embryos (and/or placentae) to rescue lethality. The concentration of Man-6-P was not determined in the embryos. However, this study clearly demonstrates that a small change in metabolite concentration during embryogenesis can have beneficial effects, but it is unclear whether this affects the placenta, embryo or both. Surprisingly, halting mannose after weaning and had no effect on their survival, subsequent growth or development. This is unlike PMM2-CDG patients who have many significant clinical issues after birth, so it is uncertain whether these mice will be useful models of the disorder. Other genetic backgrounds have not been studied to determine if this outcome is strain or laboratory specific.

\section{Mpi animal models}

Zebra fish: Morpholino-mediated knockdown of zebrafish mpi led to a dose dependent reduction in enzymatic activity and increased mortality [80]. $50 \mathrm{mM}$ mannose in the ambient water could rescue mpi morphants. There was a significant increase in Man-6-P and LLO concentrations in the embryos, which restored glycosylation, similar to therapeutic effects in humans.

Mice: $M p i$ null embryos appear normal up to E8.5, but thereafter show intrauterine growth retardation due to placental defects and die by E11.5 [39]. Concanavalin A staining of Mpinull embryos was comparable to that of WT suggesting there was not gross hypoglycosylation, which probably relied on maternal mannose. Dams were given mannose to rescue lethality, but instead, mannose dramatically accelerated embryonic death by disrupting normal placental architecture. Both embryos and placenta showed increased levels of Man-6-P. This allowed for glycosylation, but the only catabolic route to dispose of Man-6-P was blocked. Increased Man-6-P also inhibits glycolysis in yeast [82]. Earlier studies showed that mannose was toxic to honeybees, due to mutational loss of MPI that also caused Man-6-P accumulation and rapid depletion of cellular ATP [83]. A similar effect was seen by addition of mannose $(833 \mathrm{mM})$ to rat embryonic cultures that caused growth retardation and neural defects due to the inhibition of glycolysis. Glucose could overcome this mannose teratogenic effect [5].

Mouse embryonic fibroblasts ( $\mathrm{mEFs}$ ) derived from these $\mathrm{Mpi}$-null animals grow well when provided with $20 \mu \mathrm{M}$ mannose, but increasing exogenous mannose 100 and $500 \mu \mathrm{M}$ decreases growth and survival since internal Man-6-P concentration rises to $18 \mathrm{mM}$ and 28 $\mathrm{mM}$, respectively [39]. This increase depleted cellular ATP and inhibited various glycolytic enzymes including HK and phosphoglucose isomerase (PGI). 
A viable $M p i$-deficient mouse was generated by knocking-in a known MPI-CDG patient mutation causing a Y255C substitution [4]. This was shown to lead to a predicted 14\% MPI activity comparable to $7 \%$ seen in the patient fibroblasts. These mice showed the expected change in $\left[2-{ }^{3} \mathrm{H}\right]-$ Man metabolism with an increased contribution of mannose to glycosylation (increased ${ }^{3} \mathrm{H}$-label in serum glycoproteins) and reduced catabolism (reduced ${ }^{3} \mathrm{HOH}$ in serum). Surprisingly, this hypomorphic Mpi mouse appeared completely normal with none of the expected characteristics of the patients.

Mating homozygous animals gave a small, but significant decrease in the litter size, presumably due to deficient glycosylation. To correct this, dams were given 5\% mannose during conception and gestation, but instead of rescuing partial lethality, mannose caused complete embryonic lethality. This was due to accumulation of Man-6-P in both embryos and placentae, in spite of 6-7\% residual MPI activity. This result shows that both the substrate load and the amount of residual activity are important in determining the life and death outcome during embryogenesis. Reducing mannose in the water to $1 \%$ or $2 \%$ led to live births. However, there was a dose dependent toxic effect on liter size and survival to weaning [4].

Approximately 50\% pups born to dams supplemented with $1 \%$ and $2 \%$ mannose, developed ocular defects, mainly affecting the lens and amacrine cells of the retina [4] (fig. 4). No other organs were affected. Similar eye defects develop if $2 \%$ mannose was started one day post-birth since eye development continues till 4 weeks after birth. It has no effect if provided at 6-8 weeks of age. An additional factor that likely contributes to these defects is that eyes have lowest MPI activity $(1.5 \pm 0.2 \mathrm{nmols} / \mathrm{mg} / \mathrm{min})$ amongst all the major organs (varies from $7.5 \pm 0.2$ to $20.5 \pm 0.6 \mathrm{nmols} / \mathrm{mg} / \mathrm{min}$ ) tested. The eyes of $M p i$ hypomorphic mice had only $8 \%$ of normal activity, $0.124 \pm 0.025 \mathrm{nmols} / \mathrm{mg} / \mathrm{min}$. The increased mannose resulted in elevated Man-6-P in the affected eyes of these mice. The low MPI activity in the eyes was unable to cope up with increased mannose load. None of the other organs with higher residual MPI activity accumulated Man-6-P.

Besides energy depletion, accumulation of Man-6-P could cause embryonic lethality and impaired eye development by other mechanisms. For instance it could block Man-6-P receptor-mediated signaling processes, e.g. proliferin binding on fetal and maternal tissue $[84,85]$. Mannose receptors on the apical plasma membrane of retinal pigmented epithelium mediate phagocytosis of photoreceptor outer segments and is inhibited by mannose and mannans $[86,87]$. Transforming growth factor- $\beta$ (TGF- $\beta$ ) is critical for eye development. Its precursor activation is specifically inhibited by Man-6-P, but not by Man-1-P [88]. None of these potential mechanisms have been analyzed in this system.

\section{Therapeutic implications}

As discussed above, a 1.8 fold increase in dams' plasma mannose rescues lethality in Pmm2 $2^{\mathrm{R} 137 \mathrm{H} / 137 \mathrm{HL}}$ embryos [81]. The authors recommended that mothers at risk of having subsequent PMM2-CDG children could consume mannose during pregnancy to benefit the embryo in utero. This is a premature suggestion, since it has only been tested in one strain of mice. One needs to be cautious unless it is repeated and extended to other strains of mice. 
The development of PMM2 stabilizers or activators would be another therapeutic option worth considering $[89,90]$.

Successful mannose therapy for MPI-CDG patients might lead mothers at risk of having additional MPI-CDG babies to take mannose during pregnancy to overcome defects in utero. This might also be a bad decision. The 1.5-fold increase in plasma mannose seen in $\mathrm{Mpi}^{\mathrm{Y} 255 \mathrm{C} / \mathrm{Y} 255 \mathrm{C}}$ dams given $1 \%$ mannose suggests that there is a narrow window of mannose metabolic flux, which can determine life, death or gross eye malformations [4]. It is unknown whether the results seen in mice would apply to humans. The prevalence of pathological mutations in MPI and frequency of MPI-CDG births is unknown. However, the widespread use of mannose as a urinary tract health supplement is a matter of concern. The very real fear of antibiotic-resistant bacteria generates a data-supported marketing strategy for mannose, but it may be risky to a subset of pregnant women: Caution is necessary.

Other monosaccharides are potential therapeutics for specific conditions. These include fucose [91], sialic acid [92], mannosamine [93], N-acetylglucosamine [94,95], and Galactose [96]. Each of the glycan component sugars has multiple de novo biosynthetic routes, and can be salvaged from degraded glycans or absorbed from the diet [97]. There is no systematic study of the contributions of each pathway in different types of cells, the existence of potential cell surface transporters, or multiple intracellular pools. Mannose analysis as discussed here could provide a framework and model of how to approach these long overlooked aspects of "sugar metabolism".

\section{Summary}

Both diet- and glucose-derived mannose contribute to the mannose pool, which is directly used for glycoconjugate synthesis. Stringent regulation of metabolites such as Man-6-P is crucial: deficiency or excess can be detrimental for the cell and the physiology of the whole organism. Mannose can be good, bad, or ugly (Table. 2). Steady state levels and metabolic flux of the metabolites depend on both the substrates and the relevant enzymes, which in turn, determine normal vs disease states. Mannose can be a therapeutic, but indiscriminate use can have adverse effects. It is important to apply an Integrative approach to sugar metabolism. Some of the perspectives described here can inform metabolomic approaches and perspectives for other monosaccharides.

\section{Acknowledgments}

Supported by R01DK55615, R01DK099511, and The Rocket Fund.

\section{Bibliography}

1. Mersmann G, Von Figura K, Buddecke E. Storage of mannose-containing material in cultured human mannosidosis cells and metabolic correction by pig kidney alpha-mannosidase. Hoppe Seylers Z Physiol Chem. 1976; 357:641-8. [PubMed: 964924]

2. Niehues R, Hasilik M, Alton G, Körner C, Schiebe-Sukumar M, Koch HG, et al. Carbohydratedeficient glycoprotein syndrome type Ib. Phosphomannose isomerase deficiency and mannose therapy. J Clin Invest. 1998; 101:1414-20. [PubMed: 9525984]

3. Kranjčec B, Papeš D, Altarac S. D-mannose powder for prophylaxis of recurrent urinary tract infections in women: a randomized clinical trial. World J Urol. 2013 
4. Sharma V, Nayak J, Derossi C, Charbono A, Ichikawa M, Ng BG, et al. Mannose supplements induce embryonic lethality and blindness in phosphomannose isomerase hypomorphic mice. FASEB J. 2014; 28:1854-69. [PubMed: 24421398]

5. Buchanan T, Freinkel N, Lewis NJ, Metzger BE, Akazawa S. Fuel-mediated teratogenesis. Use of D-mannose to modify organogenesis in the rat embryo in vivo. J Clin Invest. 1985; 75:1927-34. [PubMed: 2409111]

6. Stewart RA, Carrico CK, Webster RL, Steinhardt RG. Physicochemical stereospecificity in taste perception of -D-mannose and -D-mannose. Nature. 1971; 234:220. [PubMed: 4943088]

7. Steinhardt RG, Calvin AD, Dodd EA. Taste-structure correlation with alpha-D-mannose and betaD-mannose. Science. 1962; 135:367-8. [PubMed: 14037773]

8. Bunn HF, Higgins PJ. Reaction of monosaccharides with proteins: possible evolutionary significance. Science. 1981; 213:222-4. [PubMed: 12192669]

9. Schallenberger, R.; Birch, G. Sugar Chemistry. Vol. Chapter 3. AVI Publishing; Westport, CT: 1975. Reactions of Sugars; p. 35-47.

10. Bhuiyan KEN, Yoshiyuki SH, Izumori I. Immobilization of 1-rhamnose isomerase and its application in 1-mannose production from l-fructose. J Ferment Eng. 1997; 84:558-562.

11. Mayo JW, Anderson RL. Pathway of L-mannose degradation in Aerobacter aerogenes. J Biol Chem. 1968; 243:6330-3. [PubMed: 5726889]

12. Herman RH. Mannose metabolism. I. Am J Clin Nutr. 1971; 24:488-98. [PubMed: 4933108]

13. Alton G, Hasilik M, Niehues R, Panneerselvam K, Etchison JR, Fana F, et al. Direct utilization of mannose for mammalian glycoprotein biosynthesis. Glycobiology. 1998; 8:285-95. [PubMed: 9451038]

14. Falcone G, Nickerson WJ. Cell-wall mannan-protein of baker's yeast. Science. 1956; 124:272-3. [PubMed: 13351642]

15. Bardalaye PC, Nordin JH. Chemical structure of the galactomannan from the cell wall of Aspergillus niger. J Biol Chem. 1977; 252:2584-91. [PubMed: 856795]

16. Horton PM. Preparation of Mannose from Ivory-Nut Shavings. J Ind Eng Chem. 1921; 13:10401041.

17. Srivastava M, Kapoor VP. Seed galactomannans: an overview. Chem Biodivers. 2005; 2:295-317. [PubMed: 17191982]

18. Tan, J.; McKenzie, C.; Potamitis, M.; Thorburn, AN.; Mackay, CR.; Macia, L. The role of shortchain fatty acids in health and disease. 1. Elsevier Inc; 2014.

19. Sharma V, Freeze HH. Mannose efflux from the cells: a potential source of mannose in blood. J Biol Chem. 2011; 286:10193-200. [PubMed: 21273394]

20. Mueckler M, Thorens B. The SLC2 (GLUT) family of membrane transporters. Mol Aspects Med. 2013; 34:121-38. [PubMed: 23506862]

21. De la Horra MC, Cano M, Peral MJ, García-Delgado M, Durán JM, Calonge ML, et al. Na(+)dependent D-mannose transport at the apical membrane of rat small intestine and kidney cortex. Biochim Biophys Acta. 2001; 1512:225-30. [PubMed: 11406099]

22. Go S, Sato C, Furuhata K, Kitajima K. Oral ingestion of mannose alters the expression level of deaminoneuraminic acid (KDN) in mouse organs. Glycoconj J. 2006; 23:411-21. [PubMed: 16897182]

23. Paulick MG, Bertozzi CR. The Glycosylphosphatidylinositol Anchor: A Complex MembraneAnchoring. 2008:6991-7000.

24. Loibl M, Strahl S. Protein O-mannosylation: what we have learned from baker's yeast. Biochim Biophys Acta. 2013; 1833:2438-46. [PubMed: 23434682]

25. Finne J, Krusius T, Margolis RK, Margolis RU. Novel mannitol-containing oligosaccharides obtained by mild alkaline borohydride treatment of a chondroitin sulfate proteoglycan from brain. J Biol Chem. 1979; 254:10295-300. [PubMed: 39937]

26. Lommel M, Strahl S. Protein O-mannosylation: conserved from bacteria to humans. Glycobiology. 2009; 19:816-28. [PubMed: 19429925]

27. Wells L. The o-mannosylation pathway: glycosyltransferases and proteins implicated in congenital muscular dystrophy. J Biol Chem. 2013; 288:6930-5. [PubMed: 23329833] 
28. Vester-Christensen MB, Halim A, Joshi HJ, Steentoft C, Bennett EP, Levery SB, et al. Mining the O-mannose glycoproteome reveals cadherins as major O-mannosylated glycoproteins. Proc Natl Acad Sci U S A. 2013; 110:21018-23. [PubMed: 24101494]

29. Luther KB, Haltiwanger RS. Role of unusual O-glycans in intercellular signaling. Int J Biochem Cell Biol. 2009; 41:1011-24. [PubMed: 18952191]

30. Tsai YH, Liu X, Seeberger PH. Chemical biology of glycosylphosphatidylinositol anchors. Angew Chem Int Ed Engl. 2012; 51:11438-56. [PubMed: 23086912]

31. Fujita M, Kinoshita T. GPI-anchor remodeling: potential functions of GPI-anchors in intracellular trafficking and membrane dynamics. Biochim Biophys Acta. 2012; 1821:1050-8. [PubMed: 22265715]

32. Stalnaker SH, Stuart R, Wells L. Mammalian O-mannosylation: unsolved questions of structure/ function. Curr Opin Struct Biol. 2011; 21:603-9. [PubMed: 21945038]

33. Dobson CM, Hempel SJ, Stalnaker SH, Stuart R, Wells L. O-Mannosylation and human disease. Cell Mol Life Sci. 2013; 70:2849-57. [PubMed: 23115008]

34. Sanyal S, Menon AK. Specific transbilayer translocation of dolichol-linked oligosaccharides by an endoplasmic reticulum flippase. Proc Natl Acad Sci U S A. 2009; 106:767-72. [PubMed: 19129492]

35. Aebi M. N-linked protein glycosylation in the ER. Biochim Biophys Acta. 2013; 1833:2430-7. [PubMed: 23583305]

36. Helenius A. Intracellular Functions of N-Linked Glycans. Science (80- ). 2001; 291:2364-2369.

37. Aebi M, Bernasconi R, Clerc S, Molinari M. N-glycan structures: recognition and processing in the ER. Trends Biochem Sci. 2010; 35:74-82. [PubMed: 19853458]

38. Chantret I, Moore SEH. Free oligosaccharide regulation during mammalian protein Nglycosylation. Glycobiology. 2008; 18:210-24. [PubMed: 18218706]

39. DeRossi C, Bode L, Eklund EA, Zhang F, Davis Ja, Westphal V, et al. Ablation of mouse phosphomannose isomerase (Mpi) causes mannose 6-phosphate accumulation, toxicity, and embryonic lethality. J Biol Chem. 2006; 281:5916-27. [PubMed: 16339137]

40. Ichikawa M, Scott DA, Losfeld ME, Freeze HH. The metabolic origins of mannose in glycoproteins. J Biol Chem. 2014; 289:6751-61. [PubMed: 24407290]

41. Gao N, Lehrman MA. Non-radioactive analysis of lipid-linked oligosaccharide compositions by fluorophore-assisted carbohydrate electrophoresis. Methods Enzymol. 2006; 415:3-20. [PubMed: 17116464]

42. Gao N, Shang J, Huynh D, Manthati VL, Arias C, Harding HP, et al. Mannose-6-phosphate regulates destruction of lipid-linked oligosaccharides. Mol Biol Cell. 2011; 22:2994-3009. [PubMed: 21737679]

43. Higashidani A, Bode L, Nishikawa A, Freeze HH. Exogenous mannose does not raise steady state mannose-6-phosphate pools of normal or N-glycosylation-deficient human fibroblasts. Mol Genet Metab. 2009; 96:268-72. [PubMed: 19157945]

44. Alton G, Kjaergaard S, Etchison JR, Skovby F, Freeze HH. Oral ingestion of mannose elevates blood mannose levels: a first step toward a potential therapy for carbohydrate-deficient glycoprotein syndrome type I. Biochem Mol Med. 1997; 60:127-33. [PubMed: 9169093]

45. Akazawa S, Metzger BE, Freinkel N. Relationships between glucose and mannose during late gestation in normal pregnancy and pregnancy complicated by diabetes mellitus: concurrent concentrations in maternal plasma and amniotic fluid. J Clin Endocrinol Metab. 1986; 62:984-9. [PubMed: 3958133]

46. Sone H, Shimano H, Ebinuma H, Takahashi A, Yano Y, Iida KT, et al. Physiological changes in circulating mannose levels in normal, glucose-intolerant, and diabetic subjects. Metabolism. 2003; 52:1019-1027. [PubMed: 12898467]

47. Mori, a; Sato, T.; Lee, P.; Furuuchi, M.; Tazaki, H.; Katayama, K., et al. Clinical significance of plasma mannose concentrations in healthy and diabetic dogs. Vet Res Commun. 2009; 33:439-51. [PubMed: 19083115]

48. Foxman B. The epidemiology of urinary tract infection. Nat Rev Urol. 2010; 7:653-60. [PubMed: 21139641] 
49. Aronson M, Medalia O, Schori L, Mirelman D, Sharon N, Ofek I. Prevention of colonization of the urinary tract of mice with Escherichia coli by blocking of bacterial adherence with methyl alphaD-mannopyranoside. J Infect Dis. 1979; 139:329-32. [PubMed: 376757]

50. Scharenberg M, Schwardt O, Rabbani S, Ernst B. Target Selectivity of FimH Antagonists. J Med Chem. 2012; 55:9810-6. [PubMed: 23088608]

51. Freeze HH, Chong JX, Bamshad MJ, Ng BG. Solving glycosylation disorders: fundamental approaches reveal complicated pathways. Am J Hum Genet. 2014; 94:161-75. [PubMed: 24507773]

52. Freeze HH, Eklund Ea, Ng BG, Patterson MC. Neurology of inherited glycosylation disorders. Lancet Neurol. 2012; 11:453-66. [PubMed: 22516080]

53. Matthijs G, Schollen E, Pardon E, Veiga-Da-Cunha M, Jaeken J, Cassiman JJ, et al. Mutations in PMM2, a phosphomannomutase gene on chromosome 16p13, in carbohydrate-deficient glycoprotein type I syndrome (Jaeken syndrome). Nat Genet. 1997; 16:88-92. [PubMed: 9140401]

54. Jaeken J, Matthijs G, Saudubray JM, Dionisi-Vici C, Bertini E, de Lonlay P, et al. Phosphomannose isomerase deficiency: a carbohydrate-deficient glycoprotein syndrome with hepatic-intestinal presentation. Am J Hum Genet. 1998; 62:1535-9. [PubMed: 9585601]

55. Freeze HH. Genetic defects in the human glycome. Nat Rev Genet. 2006; 7:537-51. [PubMed: 16755287]

56. Niehues R, Hasilik M, Alton G, Körner C, Schiebe-Sukumar M, Koch HG, et al. Carbohydratedeficient glycoprotein syndrome type Ib. Phosphomannose isomerase deficiency and mannose therapy. J Clin Invest. 1998; 101:1414-20. [PubMed: 9525984]

57. Harms HK, Zimmer KP, Kurnik K, Bertele-Harms RM, Weidinger S, Reiter K. Oral mannose therapy persistently corrects the severe clinical symptoms and biochemical abnormalities of phosphomannose isomerase deficiency. Acta Paediatr. 2002; 91:1065-72. [PubMed: 12434892]

58. Mention K, Lacaille F, Valayannopoulos V, Romano S, Kuster a, Cretz M, et al. Development of liver disease despite mannose treatment in two patients with CDG-Ib. Mol Genet Metab. 2008; 93:40-3.10.1016/j.ymgme.2007.08.126 [PubMed: 17945525]

59. Westphal V, Kjaergaard S, Davis Ja, Peterson SM, Skovby F, Freeze HH. Genetic and metabolic analysis of the first adult with congenital disorder of glycosylation type Ib: long-term outcome and effects of mannose supplementation. Mol Genet Metab. 2001; 73:77-85. [PubMed: 11350186]

60. Pedersen PS, Tygstrup I. Congenital hepatic fibrosis combined with protein-losing enteropathy and recurrent thrombosis. Acta Paediatr Scand. 1980; 69:571-4. [PubMed: 7446108]

61. Helander A, Jaeken J, Matthijs G, Eggertsen G. Asymptomatic phosphomannose isomerase deficiency (MPI-CDG) initially mistaken for excessive alcohol consumption. Clin Chim Acta. 2014; 431:15-8. [PubMed: 24508628]

62. Schroeder AS, Kappler M, Bonfert M, Borggraefe I, Schoen C, Reiter K. Seizures and stupor during intravenous mannose therapy in a patient with CDG syndrome type $1 \mathrm{~b}$ (MPI-CDG). $\mathbf{J}$ Inherit Metab Dis. 2011

63. Panneerselvam K, Etchison JR, Skovby F, Freeze HH. Abnormal metabolism of mannose in families with carbohydrate-deficient glycoprotein syndrome type 1. Biochem Mol Med. 1997; 61:161-7. [PubMed: 9259981]

64. Kjaergaard S, Kristiansson B, Stibler H, Freeze HH, Schwartz M, Martinsson T, et al. Failure of short-term mannose therapy of patients with carbohydrate-deficient glycoprotein syndrome type 1A. Acta Paediatr. 1998; 87:884-8. [PubMed: 9736238]

65. Mayatepek E, Schröder M, Kohlmüller D, Bieger WP, Nützenadel W. Continuous mannose infusion in carbohydrate-deficient glycoprotein syndrome type I. Acta Paediatr. 1997; 86:1138-40. [PubMed: 9350901]

66. Eklund EA, Merbouh N, Ichikawa M, Nishikawa A, Clima JM, Dorman Ja, et al. Hydrophobic Man-1-P derivatives correct abnormal glycosylation in Type I congenital disorder of glycosylation fibroblasts. Glycobiology. 2005; 15:1084-93. [PubMed: 16079417]

67. Koehler K, Malik M, Mahmood S, Gießelmann S, Beetz C, Hennings JC, et al. Mutations in GMPPA cause a glycosylation disorder characterized by intellectual disability and autonomic dysfunction. Am J Hum Genet. 2013; 93:727-34. [PubMed: 24035193] 
68. Carss KJ, Stevens E, Foley aR, Cirak S, Riemersma M, Torelli S, et al. Mutations in GDPmannose pyrophosphorylase B cause congenital and limb-girdle muscular dystrophies associated with hypoglycosylation of a-dystroglycan. Am J Hum Genet. 2013; 93:29-41. [PubMed: 23768512]

69. Kim S, Westphal V, Srikrishna G, Mehta DP, Peterson S, Filiano J, et al. Dolichol phosphate mannose synthase (DPM1) mutations define congenital disorder of glycosylation Ie (CDG-Ie). J Clin Invest. 2000; 105:191-8. [PubMed: 10642597]

70. Barone R, Aiello C, Race V, Morava E, Foulquier F, Riemersma M, et al. DPM2-CDG: a muscular dystrophy-dystroglycanopathy syndrome with severe epilepsy. Ann Neurol. 2012; 72:550-8. [PubMed: 23109149]

71. Lefeber DJ, Schönberger J, Morava E, Guillard M, Huyben KM, Verrijp K, et al. Deficiency of Dol-P-Man synthase subunit DPM3 bridges the congenital disorders of glycosylation with the dystroglycanopathies. Am J Hum Genet. 2009; 85:76-86. [PubMed: 19576565]

72. Imbach T, Schenk B, Schollen E, Burda P, Stutz a, Grunewald S, et al. Deficiency of dolicholphosphate-mannose synthase-1 causes congenital disorder of glycosylation type Ie. J Clin Invest. 2000; 105:233-9. [PubMed: 10642602]

73. Schenk B, Imbach T, Frank CG, Grubenmann CE, Raymond GV, Hurvitz H, et al. MPDU1 mutations underlie a novel human congenital disorder of glycosylation, designated type If. J Clin Invest. 2001; 108:1687-95. [PubMed: 11733564]

74. Kranz C, Denecke J, Lehrman MA, Ray S, Kienz P, Kreissel G, et al. A mutation in the human MPDU1 gene causes congenital disorder of glycosylation type If (CDG-If). J Clin Invest. 2001; 108:1613-9. [PubMed: 11733556]

75. Shrimal S, Ng BG, Losfeld ME, Gilmore R, Freeze HH. Mutations in STT3A and STT3B cause two congenital disorders of glycosylation. Hum Mol Genet. 2013; 22:4638-45. [PubMed: 23842455]

76. Lauc G, Vojta A, Zoldoš V. Epigenetic regulation of glycosylation is the quantum mechanics of biology. Biochim Biophys Acta. 2014; 1840:65-70. [PubMed: 23999089]

77. Davis JA, Freeze HH. Studies of mannose metabolism and effects of long-term mannose ingestion in the mouse. Biochim Biophys Acta. 2001; 1528:116-26. [PubMed: 11687298]

78. Thiel C, Lübke T, Matthijs G, von Figura K, Körner C. Targeted disruption of the mouse phosphomannomutase 2 gene causes early embryonic lethality. Mol Cell Biol. 2006; 26:5615-20. [PubMed: 16847317]

79. Cline A, Gao N, Flanagan-Steet H, Sharma V, Rosa S, Sonon R, et al. A zebrafish model of PMM2-CDG reveals altered neurogenesis and a substrate-accumulation mechanism for N-linked glycosylation deficiency. Mol Biol Cell. 2012; 23:4175-87. [PubMed: 22956764]

80. Chu J, Mir A, Gao N, Rosa S, Monson C, Sharma V, et al. A zebrafish model of congenital disorders of glycosylation with phosphomannose isomerase deficiency reveals an early opportunity for corrective mannose supplementation. Dis Model Mech. 2012000.

81. Schneider A, Thiel C, Rindermann J, DeRossi C, Popovici D, Hoffmann GF, et al. Successful prenatal mannose treatment for congenital disorder of glycosylation-Ia in mice. Nat Med. 2012; 18:71-3. [PubMed: 22157680]

82. Pitkänen JP, Törmä A, Alff S, Huopaniemi L, Mattila P, Renkonen R. Excess mannose limits the growth of phosphomannose isomerase PMI40 deletion strain of Saccharomyces cerevisiae. J Biol Chem. 2004; 279:55737-43. [PubMed: 15520001]

83. Sols A, Cadenas E, Alvarado F. Enzymatic basis of mannose toxicity in honey bees. Science. 1960; 131:297-8. [PubMed: 13832710]

84. Jackson D, Volpert OV, Bouck N, Linzer DI. Stimulation and inhibition of angiogenesis by placental proliferin and proliferin-related protein. Science. 1994; 266:1581-4. [PubMed: 7527157]

85. Lee SJ, Nathans D. Proliferin secreted by cultured cells binds to mannose 6-phosphate receptors. J Biol Chem. 1988; 263:3521-7. [PubMed: 2963825]

86. Boyle D, Tien LF, Cooper NG, Shepherd V, McLaughlin BJ. A mannose receptor is involved in retinal phagocytosis. Invest Ophthalmol Vis Sci. 1991; 32:1464-70. [PubMed: 1901835]

87. Wilt SD, Greaton CJ, Lutz DA, McLaughlin BJ. Mannose receptor is expressed in normal and dystrophic retinal pigment epithelium. Exp Eye Res. 1999; 69:405-11. [PubMed: 10504274] 
88. Dennis PA, Rifkin DB. Cellular activation of latent transforming growth factor beta requires binding to the cation-independent mannose 6-phosphate/insulin-like growth factor type II receptor. Proc Natl Acad Sci U S A. 1991; 88:580-4. [PubMed: 1846448]

89. Andreotti G, Pedone E, Giordano A, Cubellis MV. Biochemical phenotype of a common diseasecausing mutation and a possible therapeutic approach for the phosphomannomutase 2-associated disorder of glycosylation. Mol Genet Genomic Med. 2013; 1:32-44. [PubMed: 24498599]

90. Vega AI, Pérez-Cerdá C, Abia D, Gámez A, Briones P, Artuch R, et al. Expression analysis revealing destabilizing mutations in phosphomannomutase 2 deficiency (PMM2-CDG): expression analysis of PMM2-CDG mutations. J Inherit Metab Dis. 2011; 34:929-39. [PubMed: 21541725]

91. Marquardt T, Lühn K, Srikrishna G, Freeze HH, Harms E, Vestweber D. Correction of leukocyte adhesion deficiency type II with oral fucose. Blood. 1999; 94:3976-85. [PubMed: 10590041]

92. Sparks S, Rakocevic G, Joe G, Manoli I, Shrader J, Harris-Love M, et al. Intravenous immune globulin in hereditary inclusion body myopathy: a pilot study. BMC Neurol. 2007; 7:3. [PubMed: 17261181]

93. Niethamer TK, Yardeni T, Leoyklang P, Ciccone C, Astiz-Martinez A, Jacobs K, et al. Oral monosaccharide therapies to reverse renal and muscle hyposialylation in a mouse model of GNE myopathy. Mol Genet Metab. 2012; 107:748-55. [PubMed: 23122659]

94. Grigorian A, Araujo L, Naidu NN, Place DJ, Choudhury B, Demetriou M. N-acetylglucosamine inhibits T-helper 1 (Th1)/T-helper 17 (Th17) cell responses and treats experimental autoimmune encephalomyelitis. J Biol Chem. 2011; 286:40133-41. [PubMed: 21965673]

95. Salvatore S, Heuschkel R, Tomlin S, Davies SE, Edwards S, Walker-Smith Ja, et al. A pilot study of $\mathrm{N}$-acetyl glucosamine, a nutritional substrate for glycosaminoglycan synthesis, in paediatric chronic inflammatory bowel disease. Aliment Pharmacol Ther. 2000; 14:1567-79. [PubMed: 11121904]

96. Tegtmeyer LC, Rust S, van Scherpenzeel M, Ng BG, Losfeld ME, Timal S, et al. Multiple phenotypes in phosphoglucomutase 1 deficiency. N Engl J Med. 2014; 370:533-42. [PubMed: 24499211]

97. Freeze HH, Sharma V. Metabolic manipulation of glycosylation disorders in humans and animal models. Semin Cell Dev Biol. 2010; 21:655-62. [PubMed: 20363348] 


\section{Highlights}

- Mammalian plasma contains 50-100 $\mathrm{MM}$ mannose and dietary mannose supplements raise it $3-5$ fold.

- Mutations in mannose-metabolizing enzymes cause Congenital Disorders of Glycosylation (CDG).

- Mannose supplements treat phosphomannose isomerase (MPI) deficient CDG patients.

- Mannose supplements kill Mpi-hypomorphic mouse embryos and blind survivors.

- Mannose is a routine remedy for urinary tract infections. Caution, especially during pregnancy. 


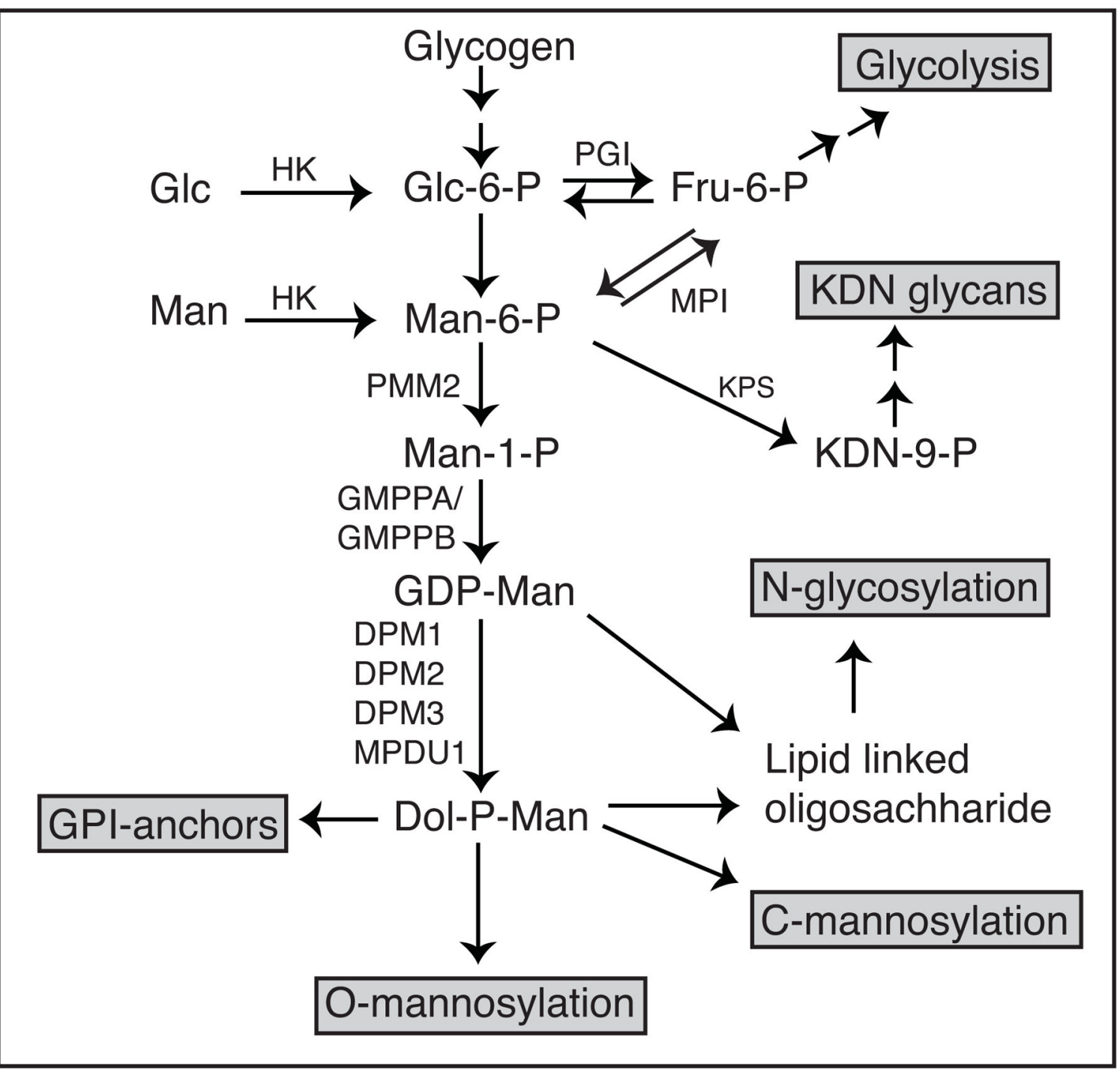

Figure 1.

Mannose Metabolic pathway: Man, Mannose; Glc, Glucose; HK, Hexokinase; MPI, phosphomannose isomerase; PMM2, phosphomannomutase; GMPP(A/B), GDP-mannose pyro-phosphorylase (A/B); PGI, phosphoglucose isomerase; KPS, KDN-9-phosphate synthase; Man-6-P, mannose-6-phosphate; Fru-6-P, fructose-6-phosphate,Glc-6-P, glucose-6-phosphate; GDP-Man, GDP-mannose; Dol-P-Man, dolichol phosphate mannose; DPM, Dol-P-Man synthase. 


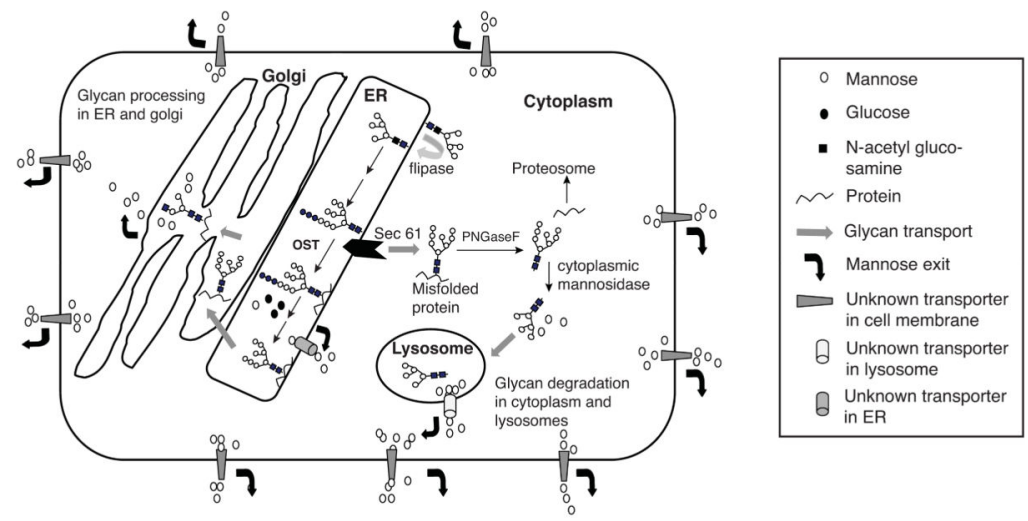

Figure 2.

Generation of free mannose inside the cell by processing and degradation. 

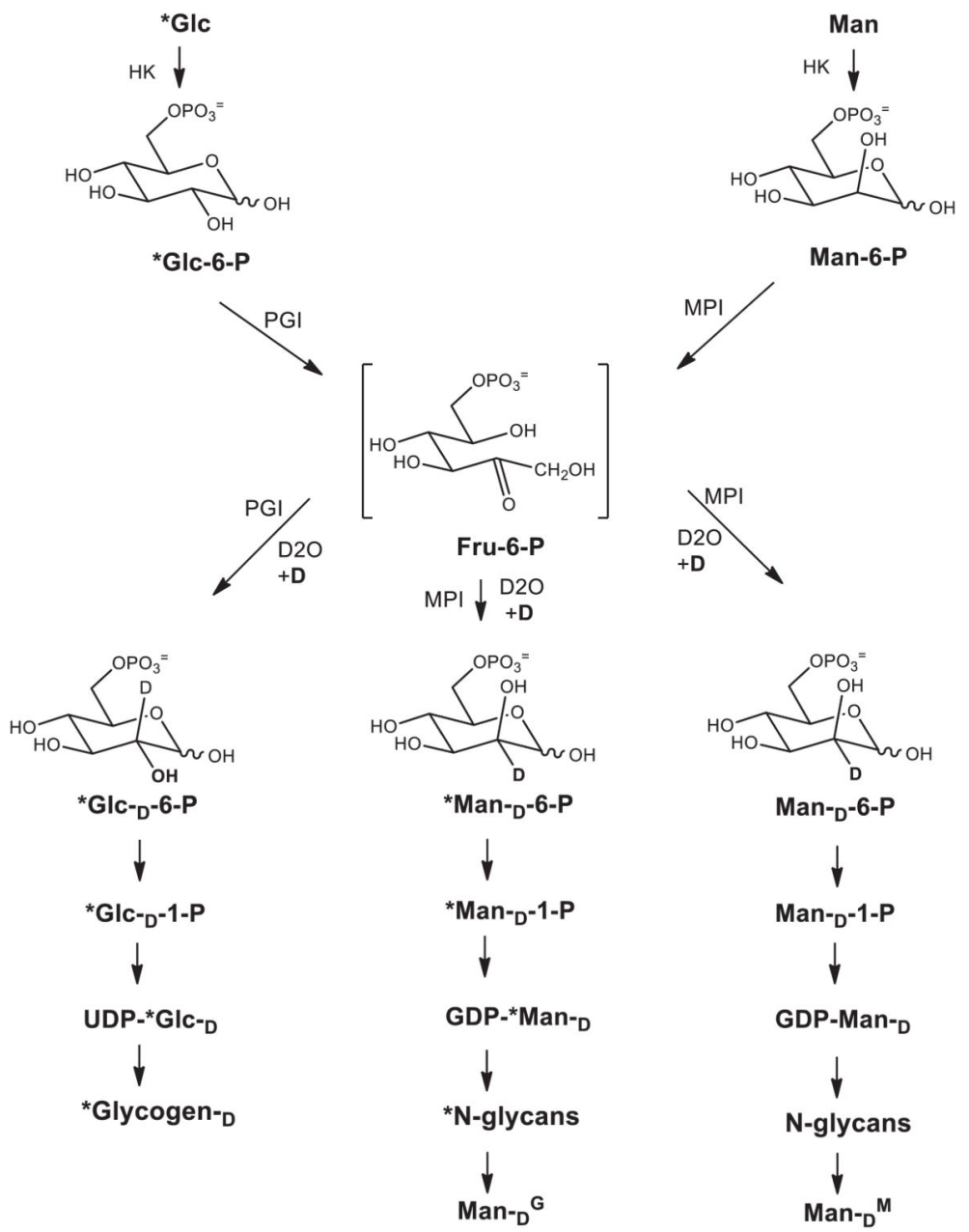

Figure 3.

Deuterium incorporation in mannose of $\mathrm{N}$-glycans from glucose $\left({ }^{*} \mathrm{Glc}\right)$ or mannose (Man) through MPI-dependent pathway. Deuterium is also incorporated in glycogen from glucose $\left({ }^{*} \mathrm{Glc}\right)$ through PGI equilibration reaction. 


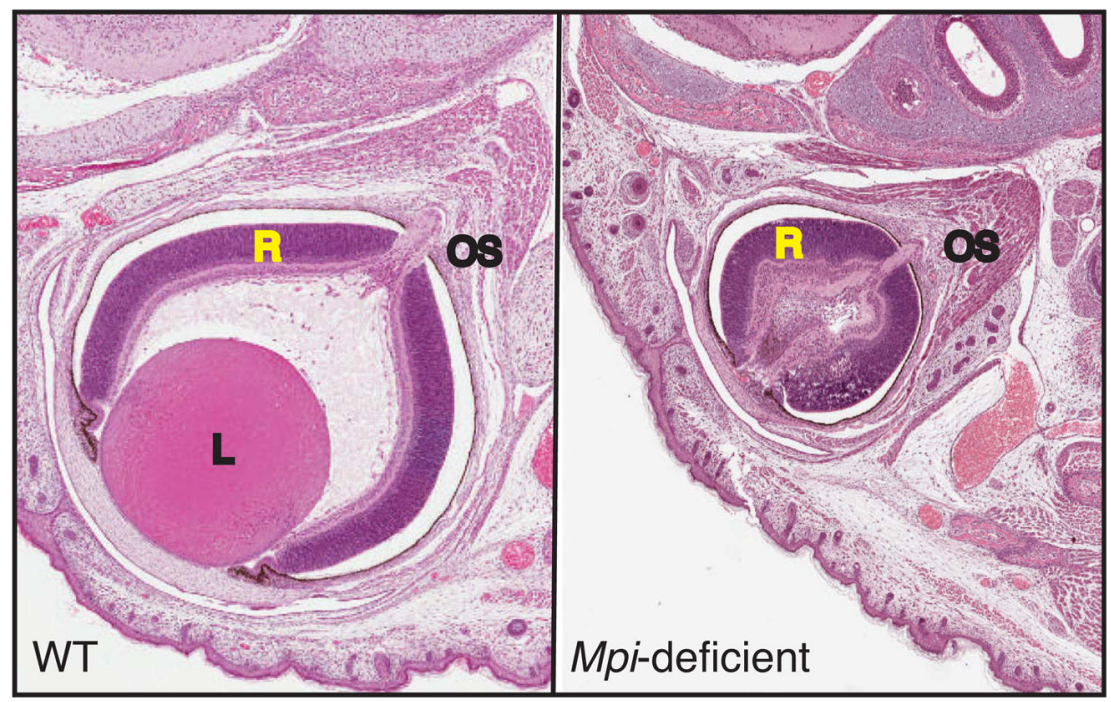

Figure 4.

Eyes from one day old WT and Mpi-hypomorphic pup born to dam supplemented with mannose before conception and throughout gestation. Mpi-deficient mouse eye was small, devoid of lens and had distorted retina. It also showed infiltration of various cells in optic cup. $\mathrm{OS}=$ optic stalk, $\mathrm{L}=$ lens, $\mathrm{R}=$ retina. 


\section{Table 1}

\section{Human Glycosylation Disorders of Mannose Metabolism}

\begin{tabular}{|c|c|c|c|c|}
\hline Disorder & Enzyme Affected & Phenotype OMIM\# & Symptoms & Reference number \\
\hline MPI-CDG & Phosphomannose isomerase & 602579 & $\begin{array}{l}\text { Hypoglycemia, } \\
\text { hepatomegaly, gastro- } \\
\text { intestinal dysfunction, } \\
\text { coagulopathy }\end{array}$ & [56] \\
\hline PMM2-CDG & Phosphomannomutase & 212065 & $\begin{array}{l}\text { Hypotonia, psychomotor } \\
\text { retardation, cerebral } \\
\text { atrophy, cerebellar } \\
\text { hypoplasia }\end{array}$ & [53] \\
\hline DPM1-CDG & $\begin{array}{l}\text { Subunit of Dol-P- Man synthase } \\
\text { complex }\end{array}$ & 608799 & $\begin{array}{l}\text { Acquired microcephaly, } \\
\text { hypotonia, cerebellar ataxia, } \\
\text { epilepsy }\end{array}$ & [69], [72] \\
\hline DPM2-CDG & $\begin{array}{l}\text { Subunit of Dol-P- Man synthase } \\
\text { complex }\end{array}$ & 615042 & $\begin{array}{l}\text { Dystroglycanopathy, } \\
\text { development delay, } \\
\text { cerebellar hypoplasia, early } \\
\text { death }\end{array}$ & [70] \\
\hline DPM3-CDG & $\begin{array}{l}\text { Subunit of Dol-P- Man synthase } \\
\text { complex }\end{array}$ & 612937 & $\begin{array}{l}\text { Muscle weakness, } \\
\text { cardiomyopathy, } \\
\text { dystroglycanopathy }\end{array}$ & [71] \\
\hline MPDU1-CDG & Mannose-P-dolichol Utilization Defect 1 & 609180 & $\begin{array}{l}\text { Muscular hypotonia, } \\
\text { gastrointestinal symptoms, } \\
\text { ichthyosis- like skin } \\
\text { disorder, intellectual } \\
\text { disability, cerebral atrophy, } \\
\text { seizures }\end{array}$ & [73], [74] \\
\hline GMPPA-CDG & GDP-mannose pyrophosphorylase A & 615510 & $\begin{array}{l}\text { Alacrima, achalasia, } \\
\text { neurological impairment }\end{array}$ & {$[67]$} \\
\hline GMPPB-CDG & GDP-mannose pyrophosphorylase B & $615350,615351,615352$ & $\begin{array}{l}\text { Limb-girdle muscular } \\
\text { dystrophy, psychomotor } \\
\text { retardation, cerebral } \\
\text { hyperplasia, retinal } \\
\text { dysfunction }\end{array}$ & [68] \\
\hline
\end{tabular}




\section{Table 2}

Mannose: The Good, The Bad and The Ugly

\begin{tabular}{|l|l|l|l|}
\hline Outcome & Disorder & System & Mannose Effect \\
\hline \multirow{4}{*}{ GOOD } & MPI-CDG & Humans & Reverses most patient symptoms except for liver fibrosis. \\
\cline { 2 - 4 } & & Zebrafish & Early intervention rescue mpi- morphants. \\
\cline { 2 - 4 } & Urinary Tract Infection & Humans & Mannose competes E.coli binding of FimH adhesins to epithelium. \\
\cline { 2 - 4 } & PMM2-CDG & Mice & Prenatal mannose rescues embryonic lethality. \\
\hline \multirow{3}{*}{ BAD/UGLY } & Diabetes & Mice & Prenatal mannose causes embryonic lethality and eye defects in the survivors. \\
\cline { 2 - 4 } & & Humans & Diabetic complication: mannose glycates proteins 5 times better than glucose. \\
\cline { 2 - 4 } & & Humans, Dogs & High mannose concentration correlates with diabetes. \\
\hline
\end{tabular}

